\title{
FERROPERICLASE - A LOWER MANTLE PHASE IN THE UPPER MANTLE
}

\author{
Gerhard P. Brey $^{1}$, Vadim Bulatov ${ }^{2}$, Andrei Girnis ${ }^{3}$, Jeff W. Harris ${ }^{4,1}$, Thomas Stachel ${ }^{5,1}$ \\ ${ }^{1}$ University of Frankfurt, Germany; ${ }^{2}$ Vernadsky Institute, Moscow, Russia; ${ }^{3}$ IGEM, Moscow, Russia; \\ ${ }^{4}$ University of Glasgow, UK; ${ }^{5}$ University of Alberta, Edmonton, Canada
}

\section{INTRODUCTION}

Ferropericlase is a major constituent of the Earth. It resides mainly in the lower mantle below the $670 \mathrm{~km}$ discontinuity, where it becomes stable through the decomposition of silicate spinel via the reaction $\mathrm{Mg}_{2} \mathrm{SiO}_{4} \rightarrow \mathrm{MgSiO}_{3}$ (perov) $+\mathrm{MgO}$ (Fe-Per). Minor amounts of periclase occur also in the earth's crust, where it forms in high-temperature contact metamorphic processes. A considerable gap in its occurrence is the upper mantle and the transition zone where the above reaction lies to the left and $\mathrm{MgO}$ is not stable in the presence of pyroxene. Thus, when Fe-Per was found as inclusion in diamonds, it was considered as an indicator of a lower-mantle origin of the host diamond. However, Stachel et al. (2000) reported evidence that ferropericlase may form as inclusion in diamonds also at upper mantle conditions provided that Si-activity was low enough.

In a collection from the Kankan district, Guinea, a diamond (KK84) was found with ferropericlase and olivine as single inclusion each and also as a contacting pair. The single olivine inclusion is identical in composition to that in contact with ferropericlase and vice versa. This demonstrates their entrapment in a single stage of diamond growth as ferropericlaseolivine pair and excludes the possibility of the formation as an original ferropericlase-ringwoodite pair in the narrow divariant field at the $670 \mathrm{~km}$-discontinuity (where ferropericlase, ringwoodite and $\mathrm{Mg}$-perovskite coexist). In the latter case ringwoodite had to transform to olivine with would necessitate $\mathrm{Fe}$ - and $\mathrm{Mg}$-exchange of the touching pair. Thus, this diamond has grown in the upper mantle in a portion with a particularly low Siactivity. Yet, the ferropericlases have elevated concentrations of $\mathrm{Na}$ and $\mathrm{Cr}$, which was considered so far to be indicative of a lower mantle origin (Kesson et al., 1998). Experimental evidence is lacking for this assumption which led us to study the solubility of $\mathrm{Na}$ at upper mantle pressures in the presence of the trivalent cations $\mathrm{Al}, \mathrm{Fe}^{3+}$ and $\mathrm{Cr}$.

\section{EXPERIMENTS}

Starting compositions along joins $\mathrm{MgO}-\mathrm{NaAlSi}_{2} \mathrm{O}_{6}$, $\mathrm{NaCrSi}_{2} \mathrm{O}_{6},-\mathrm{NaFe}^{3+} \mathrm{Si}_{2} \mathrm{O}_{6}$ were selected such that $\mathrm{MgO}$ was stable together with olivine, spinel (chromite, magnetite) and a Na-bearing phase, in our case melt. Only in the subsolidus run at $50 \mathrm{kbar}$ and $1300{ }^{\circ} \mathrm{C}$, a hitherto unknown Na- and $\mathrm{Cr}$-rich phase grew. In order to generate large amounts of periclase, the bulk $\mathrm{MgO}: \mathrm{SiO}_{2}$ was chosen to 2.5 in experiments at 1300 $1400{ }^{\circ} \mathrm{C}$ and 4.0 at $1600^{\circ} \mathrm{C}$. The mixtures were prepared from crystalline jadeite and fired oxide mixtures of $\mathrm{NaCrSi}_{2} \mathrm{O}_{6}$ and $\mathrm{NaFeSi}_{2} \mathrm{O}_{6}$ composition added in appropriate amounts to crystalline $\mathrm{MgO}$. The two latter mixtures were fired at $\sim 900^{\circ} \mathrm{C}$ in air, which provided a highly oxidized state. The experiments were carried out under dry conditions in a belt apparatus at 30 and 50 kbar and 1300,1400 and $1600^{\circ} \mathrm{C}$.

\section{Table 1: Run conditions and experimental run products}

\begin{tabular}{|c|c|c|c|c|}
\hline$P$ & $T$ & Run-Nr & Phases & Remarks \\
\hline & \multicolumn{4}{|c|}{$\mathrm{MgO}-\mathrm{NaAlSi}{ }_{2} \mathrm{O}_{6}$} \\
\hline 30 & 1300 & $295 / 2$ & $\mathrm{P}, \mathrm{ol}, \mathrm{sp}, \mathrm{L}$ & \\
\hline 30 & 1300 & 299 & P, ol, sp, L & held at 1450 \\
\hline 50 & 1300 & $1214 / 2$ & $\mathrm{P}, \mathrm{ol}, \mathrm{sp}, \mathrm{L}$ & \\
\hline 50 & 1400 & $1209 / 1$ & $\mathrm{P}, \mathrm{ol}, \mathrm{sp}, \mathrm{L}$ & \\
\hline 50 & 1400 & & & \\
\hline 50 & 1600 & $1218 / 1$ & $\mathrm{P}$, ol, sp, L & MgO-richer \\
\hline 50 & 1600 & $1221 / 1$ & P, ol, sp, L & MgO-richer \\
\hline 30 & 1300 & 300 & $\mathrm{P}$, ol, sp, L & sandwich \\
\hline \multirow[t]{2}{*}{50} & 1400 & 1216 & $\mathrm{P}, \mathrm{ol}, \mathrm{sp}, \mathrm{L}$ & sandwich \\
\hline & \multicolumn{4}{|c|}{$\mathrm{MgO}-\mathrm{NaCrSi}_{2} \mathrm{O}_{6}$} \\
\hline 30 & 1300 & $295 / 1$ & \multicolumn{2}{|l|}{$\mathrm{P}, \mathrm{ol}, \mathrm{chr}, \mathrm{L}$} \\
\hline 30 & 1300 & 296 & $\mathrm{P}$, ol, chr, L & high $\mathrm{fo}_{2}$ \\
\hline 50 & 1300 & $1214 / 1$ & $\mathrm{P}, ?$ & \\
\hline 50 & 1400 & $1209 / 2$ & $\mathrm{P}$, ol, chr, L & \\
\hline 50 & 1400 & $1215 / 2$ & $\mathrm{P}, \mathrm{ol}, \mathrm{chr}, \mathrm{L}$ & synthesis \\
\hline 50 & 1600 & $1218 / 2$ & $\mathrm{P}$, ol, chr, L & MgO-richer \\
\hline \multirow[t]{2}{*}{50} & 1600 & $1221 / 2$ & $\mathrm{P}, \mathrm{ol}, \mathrm{chr}, \mathrm{L}$ & MgO-richer \\
\hline & & \multicolumn{3}{|c|}{$\mathrm{MgO}-\mathrm{NaFe}^{3+} \mathrm{Si}_{2} \mathrm{O}_{6}$} \\
\hline 30 & 1300 & 292 & $\mathrm{P}, \mathrm{ol}, \mathrm{mt}, \mathrm{L}$ & \\
\hline
\end{tabular}

\section{Experimental Results}

Experimental run conditions and products are given in Table 1 und the compositions of the synthesized periclases in Table 2. The experimental products (except for the run at $50 \mathrm{kbar}, 1300{ }^{\circ} \mathrm{C}$ ) were always 
Table 2: Composition of synthesized periclases

\begin{tabular}{|c|c|c|c|}
\hline Run-Nr & $\mathrm{Al}_{2} \mathrm{O}_{3}$ & $\mathrm{MgO}$ & $\mathrm{Na}_{2} \mathrm{O}$ \\
\hline $295 / 2$ & 0.98 & 96.9 & 0. \\
\hline 299 & 0.87 & 96.9 & \\
\hline $1214 / 2$ & 1.06 & 96.1 & \\
\hline $1209 / 1$ & 1.49 & 94.9 & \\
\hline $1218 / 1$ & 3.64 & 94.9 & \\
\hline $1221 / 1$ & 2.56 & 94.5 & \\
\hline 300 & 0.84 & 98.4 & \\
\hline 1216 & 1.63 & 97.3 & \\
\hline
\end{tabular}

\begin{tabular}{lrrr} 
Run- $\mathbf{N r}$ & $\mathrm{Cr}_{2} \mathrm{O}_{3}$ & $\mathrm{MgO}$ & \multicolumn{2}{c}{$\mathrm{Na}_{2} \mathrm{O}$} \\
\hline $295 / 1$ & 6.18 & 89.3 & 0.78 \\
\multicolumn{1}{c}{296} & 7.1 & 89.6 & 0.65 \\
$1214 / 1$ & 8.32 & 87.3 & 1.8 \\
$1209 / 2$ & 11.5 & 84.8 & 1.58 \\
$1215 / 2$ & 10.4 & 89.2 & 0.57 \\
$1218 / 2$ & 20.7 & 77.2 & 0.77 \\
$1221 / 2$ & 21.2 & 77 & 1.21
\end{tabular}

\section{\begin{tabular}{cccc} 
Run-Nr & $\mathrm{FeO}$ & $\mathrm{MgO}$ & \multicolumn{2}{c}{$\mathrm{Na}_{2} \mathrm{O}$} \\
\hline 292 & 11.9 & 87.8 & 0.27
\end{tabular}}

periclase, olivine, spinel (chromite, magnetite) and interstitial, quenchmodified liquid. Significant amounts of $\mathrm{Na}_{2} \mathrm{O}$ were present in the synthetic periclases at all run conditions (Table 2 and Fig. 1). They duplicate the range of values observed in natural ferropericlases.

Sodium is lowest in the one Fe-bearing run, is higher at the same conditions when $\mathrm{Al}$ is present and highest in the Cr-bearing system. In the Al-bearing system Nasolubility in periclase seemingly increases with

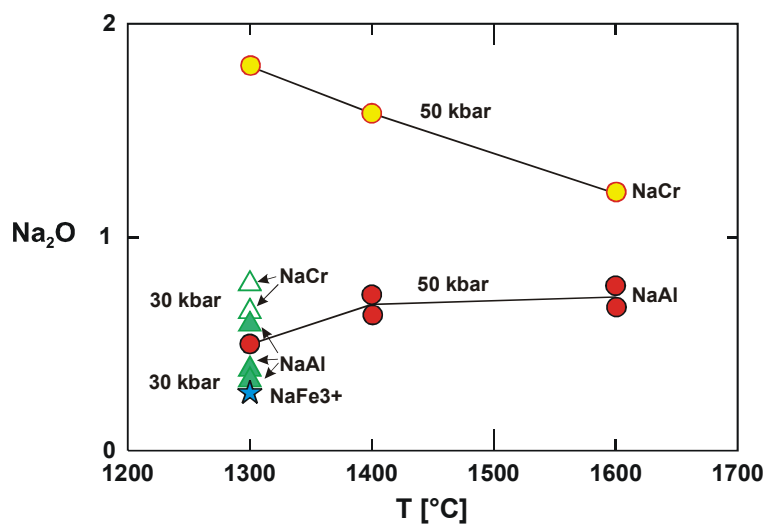

Figure 1: $\mathrm{Na}_{2} \mathrm{O}$ in periclase versus experimental temperature at 30 and $50 \mathrm{kbar}$ temperature. It decreases in the $\mathrm{Cr}$-system with temperature yet is favoured by pressure. These results cannot be applied directly to natural ferropericlases because no other Na-bearing phase is present and the coexisting melt presumably varies in amount and composition.

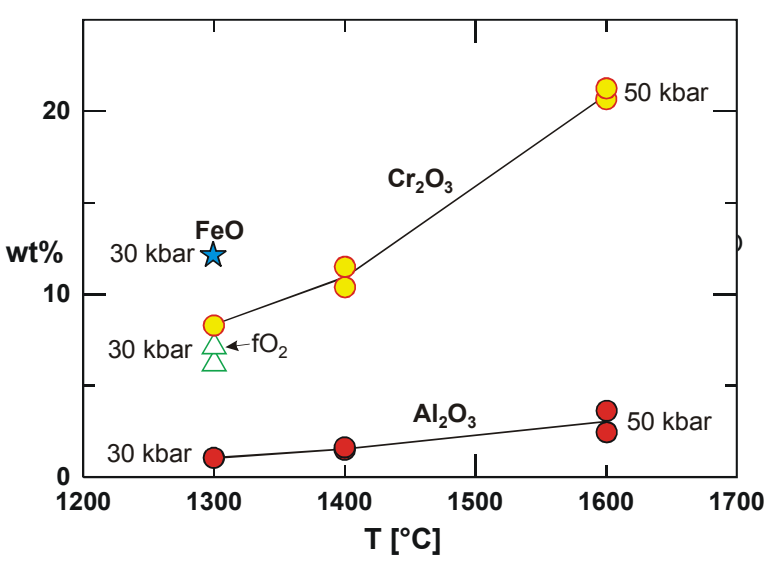

Fig.ure 2: FeO-, $\mathrm{Al}_{2} \mathrm{O}_{3}$ - and $\mathrm{Cr}_{2} \mathrm{O}_{3}$-contents in periclase versus experimental temperature at 30 and $50 \mathrm{kbar}$

$\mathrm{Al}$ and $\mathrm{Cr}$ show a positive dependency on pressure and very pronounced on temperature (Fig. 2) with $\mathrm{Cr}$ reaching more than $20 \%$ at $50 \mathrm{kbar}$ and $1600{ }^{\circ} \mathrm{C}$. These elements (esp. Cr) are incorporated into periclase in amounts far in excess of what is needed for charge balancing $\mathrm{Na}$ (Fig. 3). Al is present at 1300 and 1400 ${ }^{\circ} \mathrm{C}$ just in the correct amounts, but at $1600{ }^{\circ} \mathrm{C}$ it is double the amount of sodium and the ferropericlases must be non-stoichiometric. This is much more so the case for $\mathrm{Cr}$ which, however, may also partly be incorporated in the divalent state. Fe is also far above

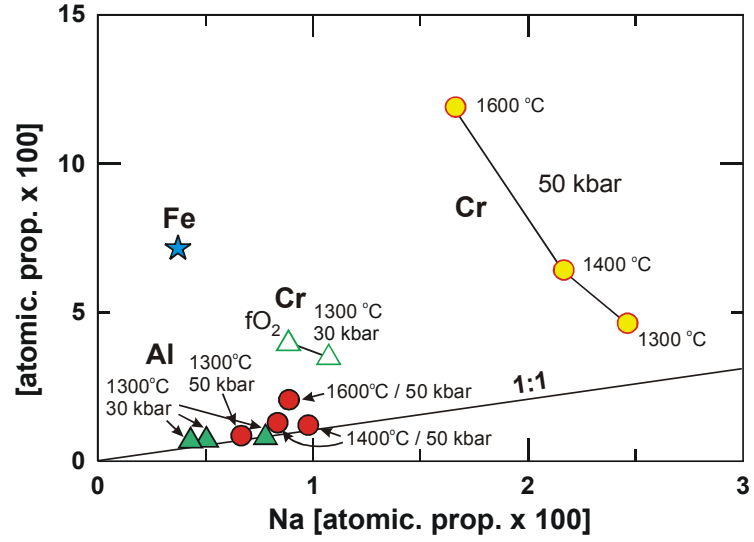

Figure 3: Atomic proportions of $\mathrm{Fe}, \mathrm{Al}$ and $\mathrm{Cr}$ versus the atomic proportion of $\mathrm{Na}$ in periclase at the various experimental conditions. The 1:1 line is the reference line for charge balance 
the amount necessary for charge balance, but much of it will be $\mathrm{Fe}^{2+}$.

The new and unknown crystalline phase produced at 50 kbar and $1300^{\circ} \mathrm{C}$ in the Cr-bearing system forms large poikilitic grains with abundant $\mathrm{MgO}$ and chromite inclusions. It is pleochroic in blue and green shades. It is extremely low in silica and Cr-rich. An idealized formula would be $\mathrm{Na}_{2} \mathrm{Mg}_{3} \mathrm{Si}_{2} \mathrm{O}_{8}$ with significant $2 \mathrm{Cr}-$ $>\mathrm{MgSi}$ and $\mathrm{NaCr}->2 \mathrm{Mg}$ isomorphism to yield $(\mathrm{Na}, \mathrm{Mg})_{2}(\mathrm{Mg}, \mathrm{Cr})_{3}(\mathrm{Si}, \mathrm{Cr})_{2} \mathrm{O}_{8}$.

\section{FERROPERICLASE-OLIVINE PAIRS IN DIAMONDS}

The olivines (structure confirmed by in-situ X-ray diffraction) in diamond KK84 are distinct from other olivine inclusions in diamonds world-wide (Fig. 4) in their extremely high $\mathrm{Mg}$-numbers (96.5) and very low $\mathrm{NiO}(0.13 \mathrm{wt} \%)$ and low $\mathrm{Cr}_{2} \mathrm{O}_{3}(0.03 \mathrm{wt} \%)$ contents, an expression of the bulk composition of the source rock and of equilibrium with ferropericlase at upper mantle pressures. The ferropericlases have high $\mathrm{Mg}$ numbers and nickel contents, together with $\mathrm{Cr}$ and $\mathrm{Na}$, fall within the range of the world-wide data base.

A second diamond (KK109) from Guinea Fig. 4) had a ferropericlase/olivine pair and two separate ferropericlases with differing composition to that from the touching pair (Stachel et al. 2000). Because of micron- to submicron spinel exsolutions and generally higher $\mathrm{Cr}$ - and $\mathrm{Al}$-contents (and also $\mathrm{Ni}$ ) in the olivine than found in the worldwide database, a case could be made that this diamond inclusion had grown near the lower mantle boundary, that the touching pair was originally ferropericlase $+\mathrm{Mg}$-perovskite and that it reacted on uprise to form ferropericlase+ringwoodite (a spinel-structure, which, in comparison to the olivinestructure, takes in trivalent cations and whose partitioning behaviour with ferropericlase is such that it takes more $\mathrm{Mg}$, Ni and Co compared to olivine). The final adjustment, but not to completion, to coexisting ferropericlase+olivine occurred in the upper mantle before the kimberlite eruption. The chemical composition of the ferropericlases falls within the spread of the worldwide database.

Diamond KK 44 seems surprising at first since it contained the three major lower mantle phases and in addition a touching pair of former Mg-perovskite (now orthopyroxene) and olivine with very low nickel (Fig. 4). This pair was originally formed as an intergrowth of small amounts of ferropericlase and abundant perovskite which kept the bulk Ni-abundance of the inclusion at a very low level. Thus, on final adjustment

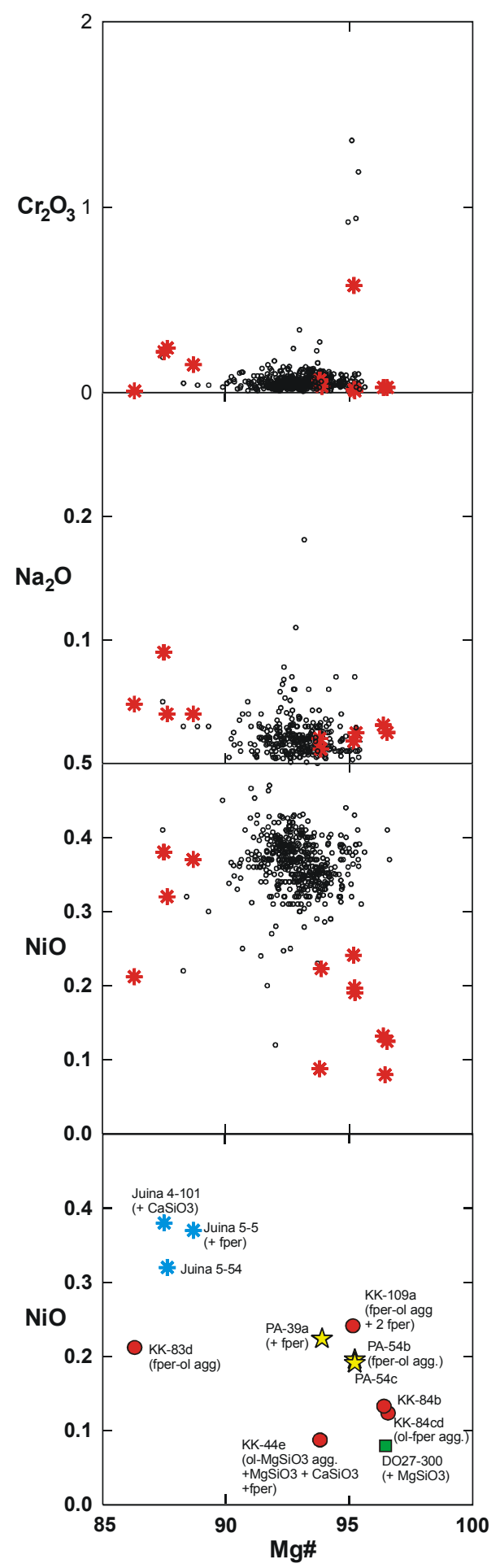

Figure 4: Composition of olivine inclusions from the world-wide data base. Olivines coexisting with ferropericlase plot away from the field of peridotitic olivines of upper mantle origin, both to low and high Niand $\mathrm{Cr}$-contents. A number of olivines plot in the vicinity of these uncommon types. 
to ambient conditions in the upper mantle, the olivine was left with only little nickel.

Two examples of joint occurrences of olivine and ferropericlase in one diamond are described from the Juina district in Brazil (Kaminsky et al., 2001 and Hutchison et al., 2001). In both cases, the ferropericlases are indistinguishable from the world data base (except for the relatively Fe-richer nature of the whole Brazilian suite), while the "olivines" show very high $\mathrm{Ni}, \mathrm{Co}$ and $\mathrm{Cr}$ (Fig. 4). In both cases the authors used this as an indication for the origin of these diamonds from the boundary to the lower mantle. A further olivine with similar high $\mathrm{Ni}, \mathrm{Co}$ and $\mathrm{Cr}$ coexists $\mathrm{CaSiO}_{3}$, fortying the conclusions about a very high pressure origin of this suite.

The diamond suite from Panda, Canada (unpublished) also yields olivine-ferropericlase pairs (PA 39, and 54), but with much lower Ni-contents in the olivines than in those in the world wide data base, but similar to those olivine-ferroperclase pairs shown to be of upper mantle origin. Diamond DO 27-300 (Davies et al., in press) has olivine and $\mathrm{Mg}$-perovskite as separate inclusions with the olivine being far too low in $\mathrm{Ni}$ and $\mathrm{Cr}$ (Fig. 4) to be a candidate as a former ringwoodite. Thus we would consider the inclusions in this diamond as a disequilibrium assembly.

From the above said, it appears that the chemistry of the ferropericlases does not allow to distinguish between an origin from the upper mantle, the transition zone or the lower mantle, but that olivines do carry this information.

\section{Single ferropericlases, single olivines}

Single ferropericlases and their chemical compositions are not indicative for a lower or an upper mantle origin. Because there is no structural change occurring in this pressure range, its uptake of suitable elements does not change drastically with pressure. Olivine, however, undergoes two phase transitions with concomitant changes in partition coefficients of divalent cations and the enhanced intake of trivalent cations. Thus, low $\mathrm{Ni}$, $\mathrm{Co}$ and $\mathrm{Cr}$-contents at high $\mathrm{Mg}$-values are indicative of an upper mantle origin and equilibrium with ferropericlase and high $\mathrm{Ni}, \mathrm{Co}$ and $\mathrm{Cr}$ at intermediate to low Mg-values of an origin in the transition zone or the boundary to the lower mantle.

\section{DISCUSSION AND CONCLUSIONS}

We have shown that sodium can be incorporated into ferropericlase at upper mantle pressures in amounts as commonly found in natural diamond inclusions. Our experiments and the diamond inclusions establish firmly that ferropericlase exists in the upper mantle in portions with low silica activity. Such portions could be a magnesite bearing dunite and ferropericlase could have formed by reduction of magnesite and during diamond growth by the following reactions:

$$
\begin{gathered}
\mathrm{MgCO}_{3}+\mathrm{CH}_{4}=\mathrm{MgO}+2 \mathrm{C}+2 \mathrm{H}_{2} \mathrm{O} \\
\text { concomitant with the Fe-Mg exchange reaction } \\
\mathrm{Mg}_{2} \mathrm{SiO}_{4}+\mathrm{FeO}=\mathrm{Fe}_{2} \mathrm{SiO}_{4}+\mathrm{MgO}
\end{gathered}
$$

The difficulty is how to generate a magnesite-bearing dunite free of orthopyroxene in the first place. This can only be via the introduction of a carbonatite melt into dunite, since carbonation reactions always generate orthopyroxene. Another scenario to be imagined is that ferropericlase crystallizes from a melt containing 8-10 wt $\% \mathrm{Na}_{2} \mathrm{O}$ (this number is deduced from our sandwich experiments not described further in this extended abstract - see table 1). Carbonated peridotite generates Na-rich carbonatite melts near the solidus (Wallace and Green, 1988) in the mantle, but it forms in equilibrium with orthopyroxene and olivine. Degassing at decreasing pressures will transform it to a silicate melt with very low Si content, which crystallizes olivine and periclase. Experimental evidence for this is presented by Brey and Ryabchikov (1994) who found a vastly extending field of crystallisation of ferropericlase in carbonated, highly Si-undersaturated magmas with decreasing pressure. This and the above model are similar except that instead of a solid carbonate we have carbonate liquid, which can easily move and produce mantle lithologies with very low $\mathrm{Si} / \mathrm{Mg}$ ratios.

In summary, ferropericlase as an inclusion in diamond on its own is not indicative of a lower mantle origin, let alone of a mantle plume. The composition of coexisting phases has to be taken into account to decide on an upper mantle, transition zone or lower mantle origin. From the presently known diamond inclusion inventory we have only clear indication that diamonds come from the upper mantle, the transition zone, from the boundary to the lower mantle and its uppermost part but not from any deeper.

\section{REFERENCES}

Brey, G.P. and Ryabchikov, I.D., 1994. Carbon dioxide in strongly undersaturated melts and origin of kimberlitic magmas.- N. Jb. Miner. Mh., H10, 449-463

Hutchison M.T., Hursthouse M.B., M.E. Light M.E., 2000. Mineral inclusions in diamonds: associations and chemical distinctions around the $670-\mathrm{km}$ discontinuity, Contrib. Mineral. Petrol. 142, 119-126 
Kaminsky R.V., Zakharchenko O.D., Davies R., Griffin W.L., Khachatryan-Blinova G.K., Shiryaev. A.A., 2000. Superdeep diamonds from the Juina area, Mato Grosso State, Brazil, Contrib. Mineral. Petrol. 140, 734-743

Kesson, S.E., Gerald J.D.F., 1992. Partitioning of MgO, $\mathrm{FeO}, \mathrm{NiO}, \mathrm{MnO}$ and $\mathrm{Cr}_{2} \mathrm{O}_{3}$ between magnesian silicate perovskite and magnesiowustite - implications for the origin of inclusions in diamond and the composition of the lower mantle, Earth Planet. Sci. Lett. 111, 229-240

Stachel, T., Harris, J.W., Brey, G.P., Joswig, W. 2000. Kankan diamonds (Guinea) II: lower mantle inclusion paragenesis, Contrib. Mineral. Petrol. 140, 34-47

Contact: Gerhard Peter Brey, Institut für Mineralogie, Universität Frankfurt, D-60054 Frankfurt, Germany, e-mail: brey@em.uni-frankfurt.de 